\title{
KOMPETENSI HUMAS PEMERINTAH DALAM MENGHADAPI REVOLUSI INDUSTRI 4.0
}

\section{THE COMPETENCE OF GOVERNMENT PUBLIC RELATIONS IN RESPONDING TO THE INDUSTRIAL REVOLUTION 4.0}

\author{
Oktolina Simatupang \\ Balai Besar Pengembangan SDM dan Penelitian Kominfo Medan \\ Kementerian Komunikasi dan Informatika Republik Indonesia \\ Jalan Tombak No. 31 Medan-20222 \\ okto001@kominfo.go.id
}

Diterima : 03 Oktober 2019

Direvisi : 25 Oktober 2019

Disetujui : 09 April 2020

\section{ABSTRACT}

Human civilization has now reached the era of industry 4.0 which is marked by the presence of Artificial Intelligence and Internet of Things. Almost all aspects of human life can not elude the exposure of industry 4.0, including public relations field. For this reason, public relations practitioners need to have the appropriate competencies to be able to deal with industry 4.0. That also applies to government public relations. The aim of this research was to identify the competence of government public relations in responding to the industrial revolution 4.0. Descriptive method with qualitative approach was used for this research. Data were gathered by conducting depth interview to 12 informants. Government public relations' competence in Aceh Provincial Government, North Sumatra Provincial Government and Riau Provincial Governmet was an issue reviewed in this study. The results showed that the government public relations' competence was not sufficient to deal with the challenge of industry 4.0.

Keywords:Public Relations, Industry 4.0, Government

\begin{abstract}
ABSTRAK
Peradaban manusia saat ini sudah sampai kepada era Industri 4.0 yang ditandai dengan kehadiran kecerdasan buatan dan Internet untuk Segala. Hampir seluruh aspek kehidupan manusia tidak bisa mengelak dari terpaan Industri 4.0 termasuk bidang kehumasan. Untuk itu, praktisi humas perlu memiliki kompetensi yang sesuai sehingga mampu berhadapan dengan Industri 4.0. Hal itu juga berlaku bagi humas pemerintah. Penelitian ini bertujuan untuk mengetahui kompetensi yang dimiliki humas pemerintah dalam menghadapi revolusi Industri 4.0. Metode yang digunakan adalah metode deskriptif dengan pendekatan kualitatif. Data diperoleh dengan melakukan wawancara mendalam kepada 12 orang informan. Kompetensi humas pemerintah di Pemerintah Provinsi Aceh, Sumatra Utara dan Riau merupakan permasalahan yang diulas dalam penelitian ini. Hasil menunjukkan bahwa kompetensi humas pemerintah belum memadai untuk menghadapi tantangan Industri 4.0.
\end{abstract}

Kata Kunci: Humas, Industri 4.0, Pemerintah

\section{PENDAHULUAN}

Seorang ekonom asal Jerman, Profesor

Klaus Schwab, memperkenalkan konsep Revolusi Industri 4.0 dalam bukunya yang berjudul "The Fourth Industrial Revolution". Menurut Schwab (Noor II, 2018), konsep tersebut telah mengubah hidup dan kerja manusia. Schwab yang juga merupakan 
pendiri dan executive chairman dari World Economic Forum, dalam bukunya tersebut memaparkan bahwa teknologi bukanlah kekuatan eksogen yang tidak dapat kita kendalikan. Kita tidak dibatasi oleh pilihan antara "menerima dan hidup dengannya" atau "menolak dan hidup tanpanya". Perubahan teknologi yang dramatis tersebut justru harus kita sikapi sebagai undangan untuk merenungkan tentang siapa kita dan bagaimana kita melihat dunia. Revolusi teknologi memiliki sifat dasar dan global yang akan memengaruhi dan dipengaruhi oleh seluruh negara, perekonomian, sektor, dan umat manusia (Schwab, 2016a).

Secara sederhana, dapat dikatakan bahwa Industri 4.0 merupakan gambaran hadirnya revolusi industri keempat menuju era Internet of Things, data, dan layanan. Industri 4.0 merupakan pergeseran paradigma dari produksi "terpusat" ke "desentralisasi". Hal ini dimungkinkan oleh kemajuan teknologi yang merupakan pembalikan dari logika proses produksi konvensional (MacDougall, 2014). Internet of Things dan dunia digital tidak dapat dipisahkan dari perubahan-perubahan yang terjadi di era globalisasi saat ini. Teknologi canggih telah memudahkan inovasi-inovasi baru untuk lahir menggantikan cara lama yang kurang efektif dan efisien. Inovasi-inovasi baru itu pun dituntut untuk dapat mengikuti kebutuhan masyarakat dan perkembangan yang terus bergerak maju (Putra, 2018). Schwab menyerukan kepada para pemimpin dan warga negara untuk bersama-sama membentuk masa depan dengan mengutamakan manusia, memberdayakan mereka dan terus-menerus mengingatkan diri kita bahwa semua teknologi baru ini adalah alat pertama dan terpenting yang dibuat oleh manusia untuk manusia (Schwab, 2016b). Revolusi industri keempat atau Revolusi Industri 4.0 dibangun di atas revolusi industri ketiga, yang juga dikenal sebagai revolusi digital, yang ditandai oleh proliferasi komputer dan otomatisasi pencatatan di semua bidang. Otomatisasi di semua bidang dan konektivitas adalah tandatanda yang nyata dari revolusi industri keempat. Salah satu petanda unik dan khusus dari revolusi industri keempat adalah munculnya aplikasi Artificial Intelligence (Tjandrawinata, 2016). Memang tidak bisa dipungkiri, era Industri 4.0 telah mengubah tidak saja tatanan proses bisnis yang ada, namun juga peran profesi di dalamnya, mulai dari sales, operation, marketing, keuangan, dan jurnalisme, dengan adanya robot yang sudah bisa menulis berita sendiri, hingga dunia kehumasan (Inspirasi, 2019).

Contoh sederhana keterampilan yang tidak bisa mengelak dari disrupsi Industri 4.0 adalah menulis, dengan kemunculan generasi narasi otomatis. Algoritma mutakhir dapat membuat narasi dalam gaya apa pun yang sesuai untuk audiens tertentu, terlihat seolah ditulis oleh manusia. Kristian Hammond, salah satu pendiri Narrative Science bahkan memperkirakan bahwa pada pertengahan tahun 2020, 90\% berita dapat dihasilkan oleh suatu algoritma, sebagian besar tanpa intervensi manusia sedikit pun (tidak termasuk desain algoritma dimaksud) (Schwab, 2016b). Apakah ini merupakan pertanda munculnya ancaman akan punahnya beberapa profesi termasuk profesi humas? Benarkah robot dan Artificial Intelligence (AI) akan menggantikan profesi humas? Jawabnya, tentu saja tidak. Kita meyakini, kompetensi humas membutuhkan kombinasi 
unik antara intuisi, nalar, empati, emosi serta kreativitas yang tidak terbatas. Hal-hal tersebutlah yang menjadi keterbatasan atau tidak dimiliki mesin AI (Inspirasi, 2019).

Sebagaimana telah disebutkan sebelumnya bahwa bidang humas juga tidak bisa terhindar dari terpaan revolusi industri. Bidang humas turut mengalami penyesuaian seiring dengan terjadinya revolusi industri yang sudah berlangsung empat tahap, yaitu:

a. Humas 1.0 adalah era ketika praktisi humas harus menjalankan tugasnya secara tradisional. Inilah era ketika humas harus melakukan monitoring secara manual setiap harinya.

b. Humas 2.0 adalah era kelahiran media online. Media seperti New York Times, The Economist, Kompas, hingga Tempo beralih ke platfrom digital. Arus informasi lalu-lalang karena awak media bisa membuat berita kapan saja, di mana saja, dan tentang apa pun. Jika di era Humas 1.0, wartawan terpaku dengan deadline di sore hari, kini setiap waktu adalah deadline.

c. Humas 3.0 adalah era ketika media sosial menjadi media yang dipercaya masyarakat. Sebuah anomali terjadi di masa ini. Jika dulu hanya wartawan yang bisa membuat berita, kini berubah. Siapa pun bisa mengunggah berita. Media seperti Facebook, Twitter, Instagram, YouTube, hingga blog menjadi digital platform. Humas bukan hanya harus memonitor media offline dan online, melainkan juga media sosial. Berita baik dan buruk bisa datang kapan saja dan oleh siapa saja.

d. Humas 4.0 adalah era ketika Artificial Intelligent (AI) dan era big data hadir. Dampak dari fenomena ini belum terasa saat ini. Namun, kenyataannya robot sudah mampu menulis artikel di media dan membantu menulis, mencari bahan, atau apa pun. Humas bukan berkompetisi dengan humas lintas negara melainkan bersaing dengan AI dan robot (Laksamana, 2018).

Bidang humas yang dimaksud tanpa terkecuali juga termasuk humas pemerintah. Dalam penelitian ini, yang menjadi fokus utama adalah humas pemerintah di Indonesia. Humas pemerintah adalah profesi yang tumbuh di era reformasi. Sejak tahun 2003, ditetapkanlah fungsional pranata humas yang diikuti dengan munculnya forum humas di lembaga pemerintah dan kementerian. Tugas humas pemerintah tidak hanya sebatas untuk membangun citra positif dan mengelola reputasi lembaga, tetapi juga untuk mengelola kepentingan publik dan pemangku kepentingan (Sugiyanto, Sumartias, Yulianita, \& Komala, 2016). Peraturan Menteri Pendayagunaan Aparatur Negara dan Reformasi Birokrasi Republik Indonesia Nomor 6 Tahun 2014 tentang Jabatan Fungsional Pranata Hubungan Masyarakat dan Angka Kreditnya, yang termaktub dalam Bab II Pasal (4) menyatakan bahwa, tugas pokok Pranata Humas adalah melakukan kegiatan pelayanan informasi dan kehumasan, yang meliputi perencanaan, pelayanan informasi dan kehumasan, hubungan eksternal dan internal, audit komunikasi kehumasan serta pengembangan pelayanan informasi dan kehumasan (Kementerian Pendayagunaan Aparatur Negara dan Reformasi Birokrasi Republik Indonesia, 2014).

Ketua Ombudsman RI, Prof. Amzulian Rifai mengatakan bahwa, tumpuan era saat ini adalah teknologi informasi dan digitalisasi. Era Industri 4.0 ini tidak bisa kita hindari. 
Kitalah yang harus beradaptasi dengan era ini. Hal ini dimaksudkan untuk meningkatkan pelayanan publik menjadi lebih baik dengan humas pemerintah yang berdiri di garda terdepan pelayan publik (Rachmawati, 2019). Ledakan internet, khususnya media sosial, telah mengubah pandangan tentang komunikasi. Saat ini media tradisional sudah bukan satu-satunya sumber informasi pemerintah dan publik yang memengaruhi pemikiran dan wacana publik. Selain itu, menurut Shirky (2008) dalam Graham \& Avery (2013), media tradisional mengakomodasi model komunikasi satu arah, tetapi kekuatan satu arah yang menghasilkan dan menyebarkan berita tersebut sebagian besar sudah usang. Kondisi ini tentu menarik untuk dikaji. Untuk itulah penelitian ini dilakukan, dengan tujuan untuk mengetahui kompetensi yang dimiliki humas pemerintah dalam menghadapi era Revolusi Industri 4.0.

Beberapa contoh penelitian mengenai kompetensi yang sebaiknya dimiliki humas pemerintah di era Revolusi Industri 4.0, antara lain adalah penelitian yang dilakukan Graham dan Avery (2013) dengan judul "Government Public Relations and Social Media: An Analysis of the Perceptions and Trends of Social Media Use at The Local Government Level". Hasil penelitian menyimpulkan bahwa di ranah media sosial yang terus berkembang, pemerintah daerah harus menemukan cara untuk memasukkan teknologi tersebut ke dalam rencana komunikasi mereka dengan cara yang menarik dan bermakna. Popularitas media sosial, rendahnya biaya, kemudahan penggunaan, dan kemampuan untuk menjangkau khalayak luas telah menjadikannya alat yang tidak dapat diabaikan oleh praktisi humas di pemerintah daerah. Pengelolaan media sosial oleh pemerintah daerah merupakan tanggung jawab petugas informasi dan komunikasi publik, yang harus mendapatkan persetujuan dan dukungan dari pejabat pemerintah, baik yang dipilih maupun yang ditunjuk. Media sosial dapat dimanfaatkan secara strategis dalam rangka mewujudkan cita-cita demokrasi. Agar warga tetap tertarik dan selalu mengunjungi situs mereka, pemerintah daerah harus melibatkan warga dengan mengirim unggahan secara teratur dan menjadikan unggahan mereka menarik dan relevan. Penting juga bagi pemerintah untuk mengintegrasikan kehadiran media sosial dengan situs web mereka dan saluran komunikasi lainnya. Pemerintah harus secara teratur memonitor pendekatan mereka untuk mengevaluasi efektivitas dan melakukan perbaikan karena media sosial adalah alat komunikasi yang dinamis dan kuat.

Meranti dan Irwansyah merumuskan bahwa, buzzer dan social media activist merupakan contoh kegiatan kehumasan yang terjadi di era Revolusi Industri 4.0. Buzzer adalah istilah yang ditujukan pada para pelaku sosial media yang melakukan kegiatan word of mouth. Word-of-mouth mengacu pada komunikasi yang terjadi antara komunikator dan komunikan yang menganggap pesan sebagai informasi nonkomersial, meskipun subjeknya adalah merek, produk, atau layanan. Media komunikasi untuk word of mouth saat ini dapat berupa email, blog, situs review konsumen dan SNS (social networking service), yang telah menjadi media utama pertukaran berita dan pengalaman (Meranti \& Irwansyah, 2018). Tantangan paling nyata di era Revolusi Industri 4.0 adalah penggunaan Artificial Intelligence (AI) atau kecerdasan buatan. Hasil penelitian Arief dan Saputra 
tentang "Kompetensi Baru Public Relations (PR) pada Era Artificial Intelligence" memperlihatkan bahwa pekerjaan yang dapat tergantikan oleh teknologi big data dan kecerdasan buatan antara lain: kliping berita (45\%); menganalisis berita di media (45\%); hubungan media dan pemangku kepentingan (37\%); manajemen konten media sosial (34\%); distribusi rilis (33\%); foto dan video (24\%). Hasil penelitian tersebut bukan mustahil akan menjadi kenyataan karena penggunaan kecerdasan buatan secara serius di bidang kehumasan memang sudah terjadi meskipun belum terlihat jelas di Indonesia (Arief \& Saputra, 2019).

Amerika Serikat adalah negara yang bisa dijadikan contoh nyata bahwa kecerdasan buatan sudah digunakan secara serius dalam bidang kehumasan. Contohnya adalah yang telah dilakukan oleh The Washington Post, surat kabar terbesar dan tertua di Amerika Serikat. Sejak 2016, The Washington Post mulai menggunakan teknologi kecerdasan buatan yang mereka ciptakan sendiri. Teknologi tersebut diberi nama Heliograf dan pertama kali digunakan untuk menghasilkan sekitar 300 berita singkat dan pemberitahuan tentang Olimpiade Rio (Moses, 2017). Selanjutnya, Heliograf digunakan untuk meliput penyelenggaraan pemilihan anggota kongres dan gubernur, pertandingan football di seluruh SMA yang ada di Washington D.C setiap minggunya, dan mengunggah kicauan seperti gambar berikut ini:

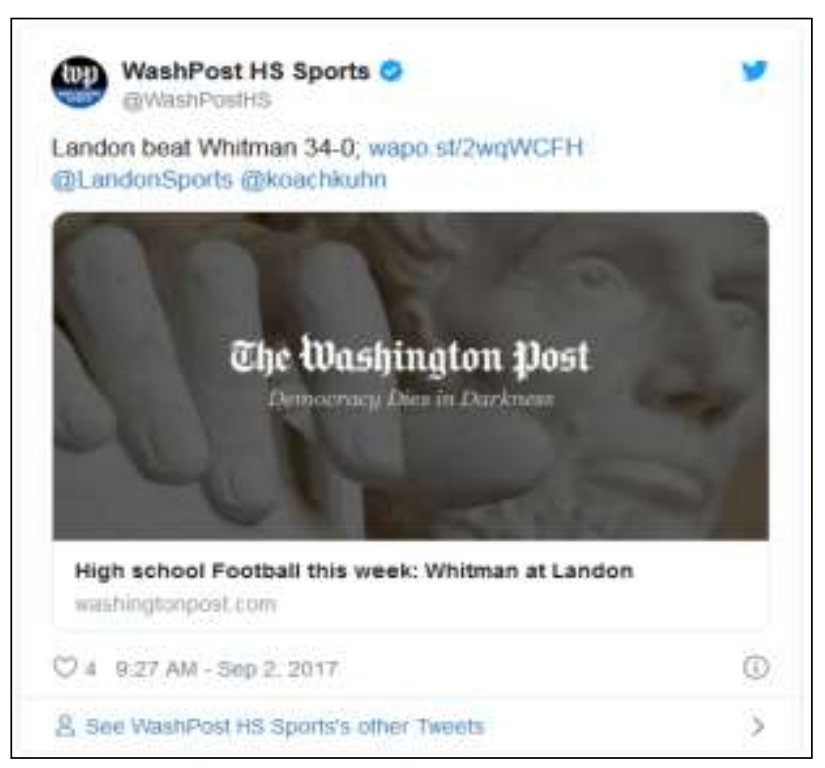

Gambar 1. Unggahan Hasil Kecerdasan

\section{Buatan}

Sumber: https://digiday.com/media/washington-postsrobot-reporter-published-500-articles-last-year/

Contoh lainnya adalah LA Times, yang mempekerjakan robot untuk mengumpulkan informasi tentang setiap peristiwa pembunuhan yang terjadi di Los Angeles, seperti terlihat pada Gambar 2.

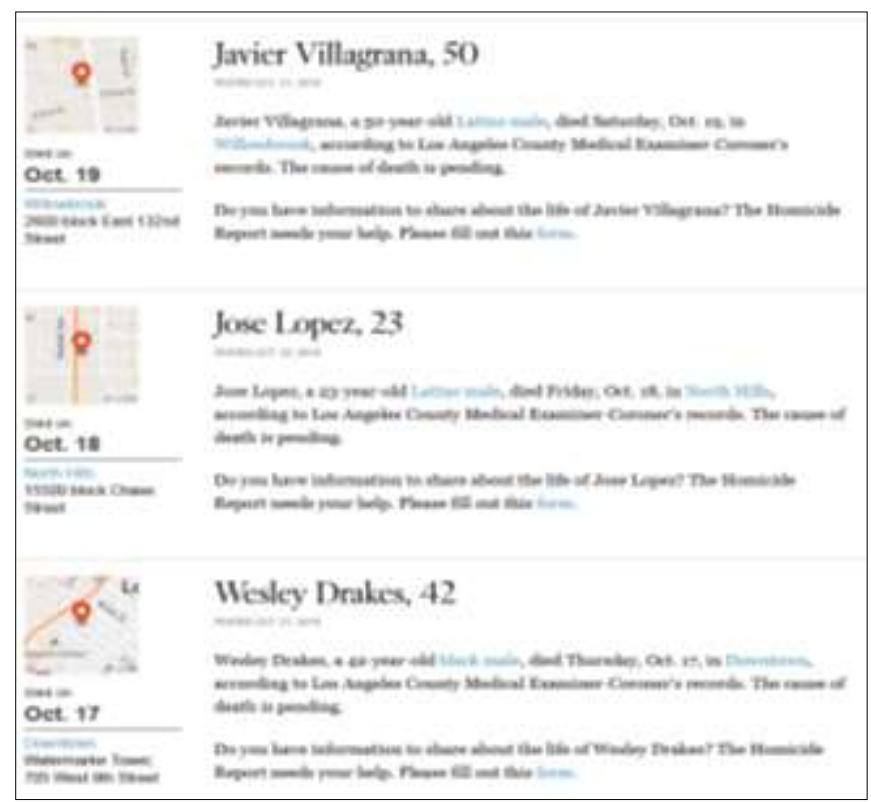

Gambar 2. Contoh Informasi Buatan

Reporter Robot

Sumber: https://homicide.latimes.com/ 
Situs bernama "Homocide Report" (laporan pembunuhan) dibuat oleh mesin dan menggunakan reporter robot yang mampu merangkum banyak data dalam laporan yang dihasilkan, termasuk ras dan jenis kelamin korban, penyebab kematian, keterlibatan petugas, lingkungan di lokasi pembunuhan dan tahun terjadinya pembunuhan. Informasi yang diproduksi oleh reporter robot tersebut kemudian ditampilkan pada situs Homocide Report yaitu homicide.latimes.com (Martin, 2019). Bentuk berita yang dikerjakan robot dengan menyajikan data tersebut, seperti pada Gambar 3 berikut ini.

\section{Man sentenced to 21 years in prison in 2017 Blue Line shooting}

By IRIS LEE

POSTED OCT. 22, 2018, 4.22 P.M.

A 22-year-old man was sentenced to 21 years in prison Thursday in the fatal shooting of a man nearly two years ago at the Compton Metro Blue Line station.

A jury on Sept. 12 convicted Arthur Lee Lewis of voluntary manslaughter in the killing of Travon Brown Jr., 21. The jury also found gun allegations against Lewis to be true.

The shooting occurred around 3:30 p.m. on Dec. 3, 2017. Lewis and his stepbrother Eric Roberts, 23, exited the Metro Blue Line train at the Compton station, yelling gang names and asking people what gang they belonged to, according to prosecutors and witness testimony at trial.

The duo approached Brown, Deputy Dist. Atty. Luke Sisak said, and a fight ensued. Roberts threw the first punch, Sisak said.

"These two guys went out looking for trouble, looking for violence, knowing they were going to use the gun," Sisak ...

Continue reading $\%$

Gambar 3. Bentuk Berita Buatan Reporter Robot Sumber: https://homicide.latimes.com/

Teknologi kecerdasan buatan ternyata juga sudah digunakan untuk merumuskan pidato untuk politisi. Valentin Kassarnig dari University of Massachusetts, Amherst, telah menciptakan mesin kecerdasan buatan yang telah belajar cara menulis pidato politik yang sangat mirip dengan pidato buatan manusia. Pendekatan yang digunakan Kassarnig secara prinsip sederhana. Kassarnig menggunakan database hampir 4.000 segmen pidato politik dari 53 debat kongres Amerika Serikat untuk melatih algoritma pembelajaran mesin menghasilkan pidato sendiri. Pidato-pidato tersebut terdiri dari lebih 50.000 kalimat yang masing-masing rata-rata berisi 23 kata. Kassarnig juga mengategorikan pidato oleh 
partai politik, baik Demokrat maupun Republik dan apakah pidato tersebut mendukung atau menentang topik tertentu. Algoritma yang digunakan kemudian mampu menentukan kemungkinan topik tertentu yang akan muncul dalam pidato. Kemudian ia memilih topik-topik dengan mencari tahu topik-topik lain yang sudah terdapat dalam pidato dan menentukan seberapa baik topik ini dibahas (EmergingTechnology from the arXiv, 2016). Berikut adalah contoh pidato Demokrat yang dihasilkan secara otomatis:

"Mr. Speaker, for years, honest but unfortunate consumers have had the ability to plead their case to come under bankruptcy protection and have their reasonable and valid debts discharged. The way the system is supposed to work, the bankruptcy court evaluates various factors including income, assets and debt to determine what debts can be paid and how consumers can get back on their feet. Stand up for growth and opportunity. Pass this legislation."

Gambar 4. Pidato Hasil Kecerdasan Buatan

Sumber: https://www.technologyreview.com/s/545606/how-an-ai-algorithm-learned-to-write-political-speeches/

Dengan adanya teknologi big data dan kecerdasan buatan, terdapat berbagai pandangan yang terpolarisasi tentang masa depan humas dan pentingnya peran humas. Dengan budaya dan model komunikasi serta kebiasaan-kebiasaan dari aktivitas humas di Indonesia, tentu muncul harapan dan keyakinan bahwa humas tidak akan pernah benar-benar mati. Masa depan profesi humas yang berfokus pada aspek manusia tetap masih diperlukan sampai dengan lima atau bahkan sepuluh tahun ke depan. Namun, praktisi humas perlu meningkatkan kemampuan dan praktik menggunakan berbagai perangkat untuk memudahkan pekerjaan (Arief \& Saputra, 2019).

Meranti dan Irwansyah dalam penelitian mereka yang berjudul "Kajian Humas Digital: Transformasi dan Kontribusi Industri 4.0 pada Strategi Kehumasan", menyimpulkan bahwa tantangan korporat di tengah era Industri 4.0 adalah mempertahankan eksistensi perusahaannya dengan memanfaatkan alatalat kehumasan di dunia digital. Strategi humas digital ini digunakan dalam rangka memaksimalkan sumber daya, dengan meliputi teknik word-of-mouth yang dilakukan oleh para buzzer, yang didukung pula oleh peran serta aktivis media sosial melalui kampanye aktivisme di dunia virtual. Tentu saja di era Industri 4.0 strategi humas digital tersebut bukan hanya berlaku bagi korporat namun juga bagi humas pemerintah (Meranti \& Irwansyah, 2018).

Dalam Industri 4.0, humas memiliki peluang besar menggunakan Internet of Things dan Internet of Service untuk menjangkau para pemangku kepentingan mereka. Revolusi industri memengaruhi peran humas dalam banyak hal. Khalayak sudah tidak lagi sama seperti sebelumnya. Era baru yang disebut milenium, mengubah cara 
mereka berinteraksi satu sama lain. Revolusi industri membawa perubahan pada saluran komunikasi yang biasanya digunakan humas. Dalam teknologi 4.0, humas dapat memanfaatkan kemajuan teknologi, karena kecerdasan buatan dapat mempelajari hal-hal baru seperti halnya manusia. Oleh karena itu, kecerdasan buatan dapat digunakan untuk mengisi celah dalam peran teknisi. Hal ini dikemukakan Binsar dan Salamah berdasarkan penelitian mereka yang berjudul "Anticipating the Post Human Era in Public Relations". Pernyataan mereka menyiratkan bahwa praktisi humas tanpa terkecuali humas pemerintah perlu memiliki kompetensi yang memadai untuk menyikapi hadirnya Revolusi Industri 4.0 (Binsar \& Salamah, 2018).

\section{METODOLOGI PENELITIAN}

Penelitian dilakukan di instansi pemerintah tingkat provinsi. Lokasi penelitian adalah Provinsi Aceh, Sumatra Utara dan Riau. Tiga provinsi tersebut adalah provinsi terluas yang berada di Sumatra bagian utara yang termasuk ke dalam sepuluh provinsi terluas di Indonesia (Databoks, 2018). Instansi pemerintah yang dipilih adalah Dinas Komunikasi dan Informatika serta Biro Humas di Sekretariat Daerah Provinsi, dengan pertimbangan bahwa pada dua OPD tersebut terdapat tugas dan fungsi kehumasan. Selain itu, ada juga dua OPD lainnya sebagai perbandingan. Pengumpulan data dilakukan pada Agustus 2018 sampai dengan September 2018.

Penelitian ini menggunakan metode deskriptif yaitu untuk menggambarkan suatu variabel, gejala atau keadaan "apa adanya" sehingga tidak dilakukan uji hipotesis (Arikunto, 2007). Di setiap OPD dilakukan wawancara mendalam dengan satu orang
ASN yang merupakan pranata humas atau memiliki tugas di bidang kehumasan. Pegawai yang menjadi key informant tersebut merupakan subjek dalam penelitian ini. Pendekatan yang digunakan dalam penelitian adalah pendekatan kualitatif.

Ibnu Hamad (Profesor Ilmu

Komunikasi Universitas Indonesia) mengatakan bahwa humas 4.0 melayani publik dengan komunikasi dan informasi melalui media berbasis internet dengan website sebagai platform dasarnya dan media sosial sebagai instrumen utama. Kompetensi yang terkait dengan pengelolaan website dan media sosial menjadi aspek yang akan digali dari informan. Hal tersebut juga mencakup kompetensi dasar seperti menulis artikel dan berita, yang sudah bisa dilakukan oleh kecerdasan buatan (robot). Kemampuan menulis berita dan artikel ini terkait dengan konten dari website OPD.

Teknik analisis data yang digunakan untuk menganalisis data adalah model Miles dan Huberman (Sugiyono, 2008). Langkahlangkah analisis data berdasarkan model tersebut yaitu reduksi data, display data (penyajian data) serta penarikan kesimpulan dan verifikasi. Mereduksi data berarti merangkum, memilih hal-hal yang pokok, memfokuskan pada hal-hal penting, serta mencari tema dan polanya. Setelah data direduksi, maka langkah selanjutnya adalah menyajikan data. Penyajian data dilakukan dalam bentuk uraian singkat, bagan, hubungan antarkategori dan sejenisnya. Selanjutnya adalah penarikan kesimpulan dan verifikasi. Kesimpulan awal yang dikemukakan masih bersifat sementara dan akan mengalami perubahan apabila tidak ditemukan bukti-bukti kuat yang mendukung pada tahap pengumpulan data berikutnya. 
Adapun pemeriksaan keabsahan data dilakukan dengan teknik triangulasi yaitu teknik pemeriksaan keabsahan data yang memanfaatkan sesuatu di luar data untuk keperluan pengecekan atau sebagai pembanding terhadap data tersebut (Moleong, 2010).

\section{HASIL DAN PEMBAHASAN}

Kegiatan-kegiatan kehumasan pada instansi pemerintah tidak hanya dikerjakan oleh fungsional pranata humas. Hal ini dikarenakan penempatan fungsional pranata humas hanya diperuntukkan bagi OPD yang memiliki tugas dan fungsi kehumasan yaitu Dinas Komunikasi dan Informatika serta Biro Humas di Sekretariat Daerah. Akan tetapi, bukan berarti di OPD lainnya tidak ada kegiatan kehumasan.

Sesuai dengan amanat Undang-Undang Nomor 14 Tahun 2008 tentang Keterbukaan Informasi Publik, maka setiap Organisasi Perangkat Daerah (OPD) wajib membentuk Pejabat Pengelola Informasi dan Dokumentasi (PPID) yang berfungsi sebagai pengelola dan penyampai dokumen yang dimiliki oleh badan publik. Untuk memenuhi amanat undangundang tersebut maka setiap OPD diwajibkan untuk memiliki website. Pengelolaan website tentunya juga memerlukan sumber daya manusia yang mengerti tentang kehumasan karena berkaitan dengan proses diseminasi informasi. Pada penelitian ini diperoleh data yang diperlukan dari 12 OPD yaitu:

Tabel 1. Organisasi Perangkat Daerah sebagai Subjek Penelitian

PROVINSI

\begin{tabular}{|c|c|}
\hline ACEH & $\begin{array}{l}\text { 1. Dinas Komunikasi, Informatika dan Persandian } \\
\text { 2. Biro Humas dan Protokol Sekretariat Daerah } \\
\text { 3. Dinas Registrasi Kependudukan } \\
\text { 4. Dinas Kelautan dan Perikanan }\end{array}$ \\
\hline $\begin{array}{l}\text { SUMATRA } \\
\text { UTARA }\end{array}$ & $\begin{array}{l}\text { 1. Dinas Komunikasi dan Informatika } \\
\text { 2. Biro Humas dan Keprotokolan Sekretariat Daerah } \\
\text { 3. Dinas Bina Marga dan Bina Konstruksi } \\
\text { 4. Dinas Perumahan dan Kawasan Pemukiman }\end{array}$ \\
\hline RIAU & $\begin{array}{l}\text { 1. Dinas Komunikasi, Informatika dan Statistik } \\
\text { 2. Biro Humas, Protokol dan Kerja Sama Sekretariat Daerah } \\
\text { 3. Dinas Ketahanan Pangan } \\
\text { 4. Dinas Kelautan dan Perikanan }\end{array}$ \\
\hline
\end{tabular}

Sumber: Pengolahan Data

Berdasarkan hasil wawancara diketahui bahwa tugas-tugas kehumasan ada di semua OPD. Hal ini dibuktikan dengan keberadaan website di masing-masing OPD. Namun, ASN yang diberi tanggung jawab untuk mengerjakan tugas kehumasan di setiap OPD tersebut tidak semuanya adalah pejabat fungsional pranata humas. Website dari setiap OPD tersebut dapat diakses pada link sebagai mana yang tercantum pada tabel berikut ini: 
Tabel 2. Alamat Website OPD Subjek Penelitian

Nama OPD

Alamat Website

1. Dinas Komunikasi, Informatika dan Persandian Provinsi Aceh

2. Biro Humas dan Protokol Sekretariat Daerah Provinsi Aceh

3. Dinas Registrasi Kependudukan Provinsi Aceh

4. Dinas Kelautan dan Perikanan Provinsi Aceh

5. Dinas Komunikasi dan Informatika Provinsi Sumatra Utara

6. Biro Humas dan Keprotokolan Sekretariat Daerah Provinsi Sumatra Utara

7. Dinas Bina Marga dan Bina Konstruksi Provinsi Sumatra Utara

8. Dinas Perumahan dan Kawasan Pemukiman Provinsi Sumatra Utara

9. Dinas Komunikasi, Informatika dan Statistik Provinsi Riau

10. Biro Humas, Protokol dan Kerja Sama Sekretariat Daerah Provinsi Riau

11. Dinas Ketahanan Pangan Provinsi Riau

12. Dinas Kelautan dan Perikanan Provinsi Riau

Sumber: Hasil Observasi

Organisasi Perangkat Daerah yang memiliki pejabat fungsional Pranata Humas hanya Biro Humas, Protokol dan Kerja Sama Sekretariat Daerah Provinsi Riau, yaitu sebanyak tiga orang. Adapun di OPD lainnya tidak ditemukan pejabat fungsional Pranata Humas sehingga tugas kehumasan dikerjakan oleh pegawai nonpranata humas. Selain itu, sebagian besar ASN yang mengerjakan tugas kehumasan tidak memiliki latar belakang pendidikan kehumasan.

Mengenai penggunaan teknologi dalam bekerja, ditemukan bahwa penggunaan teknologi masih terbatas pada perangkat komputer yaitu menggunakan aplikasi drka.acehprov.go.id

diskominfo.acehprov.go.id

humas.acehprov.go.id

dkp.acehprov.go.id

diskominfo.sumutprov.go.id

humas.sumutprov.go.id

binamarga.sumutprov.go.id

dispkp.sumutprov.go.id

diskominfotik.riau.go.id

humas.riau.go.id/home

diskepang.riau.go.id

dkp.riau.go.id perkantoran seperti pengolah kata, pengolah angka dan pengolah presentasi. Peralatan teknologi tersebut dipilih karena tugas kehumasan yang bisa dikerjakan terbatas pada penulisan berita dan artikel untuk keperluan mengisi konten website.

Kemampuan menulis perlu disikapi serius di era Revolusi Industri 4.0. Namun patut disayangkan karena kemampuan menulis ASN yang mengerjakan tugas kehumasan ternyata kurang mumpuni. Seperti pernyataan Evi dari Dinas Bina Marga dan Bina Konstruksi Sumatra Utara. Evi yang diberi tanggung jawab untuk mengelola website menuturkan bahwa, sebagai sarjana 
teknik sipil yang tidak punya pengalaman di bidang kehumasan, dirinya merasa kurang maksimal dalam mengerjakan tugas kehumasan, terutama pada penulisan berita dan artikel yang baik dan benar. Selama diberi tugas di bidang kehumasan, Evi belum pernah mengikuti pelatihan untuk meningkatkan kemampuan, setidaknya dalam hal menulis berita dan artikel yang harus dimuat di website.

Proses editing berita dan artikel juga harus dilakukan sendiri. Adapun untuk fotofoto kegiatan yang diberitakan, Evi menggunakan hasil dokumentasi pegawai yang berada di tempat kegiatan. Tidak ada fotografer khusus. Foto-foto diperoleh dari kiriman foto pada grup WhatsApp dinas atau dikirim langsung oleh pegawai yang berada di lokasi kegiatan. Foto-foto tersebut digunakan sebagaimana adanya tanpa proses editing dan tanpa menghiraukan kualitas foto karena memang tidak ada SDM yang bisa melakukannya.

Tidak jauh berbeda dengan yang ada di Biro Humas Protokol dan Kerja Sama Sekretariat Daerah Riau. Sebagaimana yang disampaikan Kanti Amalia, bahwa tenaga kehumasan di satuan kerjanya memiliki kemampuan menulis yang masih terbatas. Tanggung jawab penulisan naskah pidato diserahkan kepada 2 orang pranata humas, sedangkan untuk penulisan artikel dan berita dikerjakan oleh tenaga honorer. Penyebabnya bukan karena ketidakmampuan ASN tetapi karena keterbatasan jumlah ASN yang mampu untuk mengerjakannya. Pranata humas yang ada lebih banyak diberi penugasan untuk menulis pidato mengingat banyaknya acara protokoler.

Demikian juga untuk urusan fotografi dan videografi yang masih terkendala jumlah
ASN sehingga tugas fotografi dan videografi harus diserahkan kepada tenaga honorer. Biro Humas Protokol dan Kerja Sama Sekretariat Daerah Riau hanya memiliki dua orang ASN yang punya kemampuan fotografi. Jumlah tersebut tentu tidak ideal bagi satuan kerja yang memerlukan banyak tugas peliputan. Dari segi hasil, kualitas foto dan video yang dihasilkan juga belum sepenuhnya sesuai dengan prinsip dasar fotografi yaitu menggunakan rule of third, pencahayaan dan komposisi foto menarik (Mahany, 2016).

Lemahnya kemampuan menulis juga diakui oleh Reza Kadir, ASN yang mengelola website di Dinas Ketahanan Pangan Riau. Menurut Reza, mereka masih perlu memahami komputerisasi dan TIK karena saat ini segala sesuatu berhubungan dengan teknologi, misalnya cara cepat mengumpulkan informasi melalui HP, email, dan lain sebagainya. Reza juga mengakui bahwa kemampuan dalam hal teknik penulisan berita masih belum optimal. Dinas Komunikasi, Informatika dan Persandian Aceh juga tidak luput dari minimnya kemampuan menulis. Mengikutsertakan ASN pada pelatihan kehumasan untuk meningkatkan kemampuan mereka juga tidak maksimal karena kebanyakan mereka sudah tua dan pelatihan yang ditawarkan bukan merupakan bidang pekerjaan mereka sehingga mereka tidak berminat. Yang lebih berminat dengan pelatihan tersebut justru tenaga honorer. Informasi tersebut disampaikan oleh Asriani, ASN yang bertugas di bidang kehumasan di Dinas Komunikasi, Informatika dan Persandian Aceh.

Kondisi di OPD lainnya tidak jauh berbeda. Upaya meningkatkan kemampuan ASN yang bertugas di kehumasan terkendala beberapa masalah, seperti tidak ada dana, 
tidak ada kesempatan, dan ada kalanya ASN yang diikutsertakan untuk pelatihan bukan yang bertugas di kehumasan.

Selain itu, ASN yang mengerjakan tugas kehumasan sebagian besar adalah ASN yang usianya sudah tua sehingga kurang tepat untuk mengikuti pelatihan karena kurang berminat. Merekrut pegawai baru juga belum memungkinkan dilakukan karena terganjal moratorium.

Problem yang dialami Biro Humas dan Keprotokolan Sekretariat Daerah Sumatra Utara lebih pelik lagi. Satuan kerja ini baru dibentuk pada tahun 2017. Seluruh staf di biro ini berasal dari satuan kerja lain yang tidak punya keahlian dalam pekerjaan kehumasan. Aparatur Sipil Negara yang memiliki kemampuan kehumasan hanya delapan orang dan itu pun sangat mendasar seperti menulis berita. Biro Humas dan Keprotokolan Sekretariat Daerah Sumatra Utara tidak punya pilihan selain merekrut tenaga honorer untuk mendukung pekerjaan mereka. Ada sekitar 19 tenaga pendukung yang dipekerjakan karena memiliki kemampuan sesuai kebutuhan instansi yaitu desain grafis, menulis berita, web developer, fotografi dan videografi. Tenaga pendukung yang notabene bukan ASN tersebut juga diberi tanggung jawab untuk mengelola website instansi.

Pada OPD selain Biro Humas dan

Dinas Kominfo, tugas kehumasan bukanlah tugas utama dari ASN yang diberi tanggung jawab sehingga mereka mengerjakan tugas kehumasan dengan kemampuan yang terbatas. Mereka juga tidak bisa memprioritaskan tugas kehumasan karena harus mengutamakan tugas pokok mereka. Selain itu, mereka juga tidak bisa berharap banyak untuk diikutsertakan pada setiap pelatihan tentang kehumasan karena tugas pokok dan fungsi utama instansi mereka bukan bidang kehumasan. Hal inilah yang seringkali menjadi penyebab OPD-OPD tersebut tidak diundang untuk mengikuti pelatihan kehumasan.

Kondisi di setiap OPD pada penelitian ini memperlihatkan bahwa ASN yang mengerjakan tugas kehumasan di masingmasing OPD memiliki kemampuan yang terbatas untuk berhadapan dengan Revolusi Industri 4.0. Kemampuan petugas humas dalam menulis berita dan artikel masih perlu ditingkatkan padahal perkembangan teknologi sudah berhasil menciptakan kecerdasan buatan yang mampu menulis berita, artikel bahkan pidato. Sebagai contoh seperti yang telah dipaparkan pada bagian pendahuluan yaitu kecerdasan buatan yang digunakan suratkabar The Washington Post untuk menulis berita dan LA Times dalam produksi rilis berita. Fotografi dan videografi juga diprediksi akan bisa dikerjakan oleh kecerdasan buatan.

Media penyebaran informasi yang digunakan oleh semua OPD pada penelitian ini masih mengutamakan website, padahal di era Revolusi Industri 4.0 media sosial lebih dinimati oleh khalayak, khususnya kaum milenial. Pada saat penelitian ini dilakukan, baru Biro Humas, Protokol dan Kerja Sama, Sekretariat Daerah Provinsi Riau yang sudah menggunakan media sosial sebagai salah satu media untuk menyampaikan informasi. Media sosial yang mereka gunakan adalah Instagram dengan nama akun humas_riau (https://www.instagram.com/humas_riau/).

Unggahan pertama di akun Instagram tersebut bertanggal 25 September 2017 berupa foto acara Tabligh Akbar Peringatan Tahun Baru Islam $1439 \mathrm{H}$.

Jika penguasaan teknologi hanya sebatas penggunaan komputer dan aplikasi 
perkantoran maka dikhawatirkan humas pemerintah akan kewalahan menghadapi era Revolusi Industri 4.0. Kemampuan ASN yang diberi tanggung jawab mengerjakan tugas kehumasan perlu ditingkatkan, termasuk dalam hal menggunakan perangkat teknologi selain komputer dan aplikasi selain perkantoran.

\section{KESIMPULAN DAN SARAN}

Revolusi Industri 4.0 tidak bisa dihindari dan tidak bisa dicegah untuk terjadi. Semua pihak, mau tidak mau, siap tidak siap, harus berhadapan dengan konsekuensi Revolusi Industri 4.0. Humas pemerintah akan menghadapi tuntutan pekerjaan yang bersinggungan dengan produk Industri 4.0 seperti kecerdasan buatan dan Internet of Things. Kompetensi humas pemerintah, khususnya di Pemerintah Provinsi Aceh, Sumatra Utara dan Riau belum memenuhi tuntutan ideal agar mampu berhadapan dengan tantangan Industri 4.0. Setidaknya, untuk ruang lingkup pengelolaan website dengan kemampuan dasar yang meliputi penulisan berita, penulisan artikel, fotografi dan videografi, ternyata masih belum ideal. Kemampuan dasar penulisan berita dan artikel tentunya menggunakan formula $5 \mathrm{~W}+1 \mathrm{H}$. Adapun untuk fotografi, setidaknya ASN harus menguasai kemampuan dasar yaitu memahami sudut pandang (angle), bidang pandang (framing), hukum sepertiga (the rule of third), pergerakan kamera, dan termasuk juga proses editing. Padahal di era Revolusi Industri 4.0, humas pemerintah tidak bisa mengelak untuk berhadapan dengan kecerdasan buatan.

Permasalahannya adalah tidak semua tugas-tugas kehumasan tersebut ditangani oleh pegawai yang memiliki latar belakang pendidikan kehumasan. Selain itu, tugas kehumasan dikerjakan oleh ASN yang juga memiliki keterampilan terbatas. Latar belakang pendidikan formal bidang kehumasan memang tidak harus menjadi indikator mutlak seseorang mampu mengerjakan tugas-tugas kehumasan. Pada OPD selain Dinas Komunikasi dan Informatika serta Biro Humas Sekretariat Daerah, maka tugas kehumasan dikerjakan oleh pegawai yang tidak memiliki latar belakang pendidikan formal bidang kehumasan. Namun bukan berarti mereka secara keseluruhan buta sama sekali tentang kehumasan. Ada beberapa pegawai yang memang berbakat untuk melakukan tugas tersebut dan ada juga yang mengerjakan dengan kemampuan seadanya.

Kemampuan menulis, fotografi dan videografi (termasuk proses editing foto dan video), merupakan kompetensi yang belum optimal dimiliki oleh pegawai kehumasan di semua OPD yang diteliti. Padahal, kemampuan tersebut merupakan keahlian mendasar yang penting dimiliki oleh humas pemerintah, setidaknya untuk keperluan pengelolaan website instansi. Keberadaan media sosial untuk diseminasi informasi pemerintah juga belum dimanfaatkan dengan optimal.

Meskipun ASN yang mengerjakan tugas kehumasan pemerintah pada umumnya tidak memiliki latar belakang pendidikan formal dalam bidang kehumasan, bukan berarti keterampilan tersebut tidak bisa dipelajari secara otodidak dan mandiri. Perkembangan TIK yang pesat saat ini sangat memungkinkan bagi SDM humas pemerintah untuk mempelajari banyak hal. Inisiatif dari pegawai bersangkutan juga perlu didorong sehingga masing-masing aktif membekali diri 
dan terus meningkatkan kemampuan di bidang kehumasan agar tidak kalah bersaing dengan kecerdasan buatan.

Humas pemerintah diharapkan lebih kreatif dalam melakukan tugas-tugas kehumasan, khususnya diseminasi informasi pemerintah. Media yang digunakan perlu diperluas sehingga tidak hanya sebatas website instansi saja. Kehadiran media sosial yang sangat digemari masyarakat terutama kaum milenial menjadi tantangan sekaligus peluang bagi humas pemerintah. Pemerintah perlu menyediakan pelatihan-pelatihan untuk pengembangan diri yang sesuai dengan kebutuhan humas pemerintah untuk menghadapi Revolusi Industri 4.0.

\section{UCAPAN TERIMA KASIH}

Penulis mengucapkan terima kasih kepada semua pihak yang sudah berperan sehingga penelitian bisa terlaksana dan artikel ini bisa diselesaikan. Ucapan terima kasih diucapkan secara khusus kepada reviewer yang telah memberikan masukan, saran dan kritik demi kesempurnaan tulisan. Demikian juga kepada semua informan dan semua OPD yang berkenan untuk memberikan data.

\section{DAFTAR PUSTAKA}

Arief, N. N., \& Saputra, M. A. A. (2019).

Kompetensi Baru Public Relations (PR) Pada Era Artificial Intelligence. Jurnal Sistem Cerdas, 02(01), 1-12.

Arikunto, S. (2007). Manajemen Penelitian. Jakarta: Rineka Cipta.

Binsar, A., \& Salamah, U. (2018). Anticipating the Post Human Era in Public Relations. In 2nd Indonesia International Graduate Conference on Communication (Indo-ICC) Proceeding (pp. 373-392).
Databoks. (2018). Ini Urutan Provinsi Terluas di Indonesia. Retrieved September 19, 2019 , from https://databoks.katadata.co.id/datapubli sh/2018/01/16/perbandingan-luaswilayah-provinsi-indonesia

EmergingTechnology from the arXiv. (2016). How an AI Algorithm Learned to Write Political Speeches. Retrieved October 24, 2019, from https://www.technologyreview.com/s/5 45606/how-an-ai-algorithm-learned-towrite-political-speeches/

Graham, M., \& Avery, E. J. (2013). Government Public Relations ad Social Media: An Analysis of the Perceptions and Trends of Social Media Use at the Local Government Level. Public Relations Journal, 7(4), 1-21.

Inspirasi. (2019). Transformasi Humas dalam Era Revolusi 4.0. Bamboedoea, 1-2. Retrieved from http://bamboedoea.com/wpcontent/uploads/2019/03/Inspirasi-

Edisi-20-8-halaman-4.pdf

Kementerian Pendayagunaan Aparatur Negara dan Reformasi Birokrasi Republik Indonesia. (2014). Peraturan Menteri Pendayagunaan Aparatur Negara dan Reformasi Birokrasi Republik Indonesia Nomor 6 Tahun 2014 Tentang Jabatan Fungsional Pranata Hubungan Masyarakat dan Angka Kreditnya.

Laksamana, A. (2018). Humas Indonesia Menuju Industri 4.0. Retrieved from https://www.wartaekonomi.co.id/read18 2081/humas-indonesia-menuju-industri40.html

MacDougall, W. (2014). Industrie 4.0 Smart Manufacturing for the Future. (J. Hull 
\& S. Sasse, Eds.). Berlin: Germany Trade \& Invest.

Mahany, A. T. (2016). Tips Mudah Hasilkan

Foto Keren Ala Darwis Triadi Untuk

Para Pemula. Retrieved April 6, 2020, from https://www.brilio.net/news/tipsmudah-hasilkan-foto-keren-ala-darwistriadi-untuk-para-pemula-160121c.html

Martin, N. (2019). Did Robot Write This? How AI is Impacting Jornalism. Retrieved October 23, 2019, from https://www.forbes.com/sites/nicolemar tin1/2019/02/08/did-a-robot-write-thishow-ai-is-impactingjournalism/\#338c7bba7795

Meranti, \& Irwansyah. (2018). Kajian Humas Digital: Transformasi dan Kontribusi Industri 4.0 Pada Stratejik Kehumasan. Jurnal Teknologi Informasi Dan Komunikasi, 7(1), 27-36.

Moleong, L. J. (2010). Metodologi Penelitian Kualitatif. Bandung: PT Remaja Rosdakarya.

Moses, L. (2017). The Washington Post's Robot Reporter Has Published 850 Articles in The Past Year. Retrieved October 23, 2019, from https://digiday.com/media/washingtonposts-robot-reporter-published-500articles-last-year/

Noor II, A. R. (2018). Mengenal Konsep Revolusi 4.0. Retrieved September 24, 2019, from https://inet.detik.com/business/d4041437/mengenal-konsep-revolusiindustri-40
Putra, R. M. D. (2018). Inovasi Pelayanan Publik di Era Disrupsi (Studi Tentang Keberlanjutan Inovasi E-Health di Kota Surabaya). Kebijakan Dan Manajemen Publik, 6(2), 1-13.

Rachmawati, D. (2019). Kerja Humas Pemerintah 4.0 Harus Sejalan Dengan Semangat Internet of Things. Retrieved September 19, 2019, from https://bkhh.lipi.go.id/kerja-humaspemerintah-4-0-harus-sejalan-dengansemangat-internet-of-things/

Schwab, K. (2016a). The Fourth Industrial Revolution: What It Means, How to Respond. Retrieved September 24, 2019, from https://www.weforum.org/agenda/2016/ 01/the-fourth-industrial-revolutionwhat-it-means-and-how-to-respond/

Schwab, K. (2016b). The Fourth Industrial Revolution. Geneva: World Economic Forum.

Sugiyanto, D. R., Sumartias, S., Yulianita, N., \& Komala, L. (2016). Professional Government Public Relations in Indonesia: A Review. Journal of Education and Social Science, 3, 53-60.

Sugiyono. (2008). Metode Penelitian Kualitatif dan $R \& D$. Bandung: Alfabeta.

Tjandrawinata, R. R. (2016). Industri 4.0: Revolusi Industri Abad ini dan Pengaruhnya Pada Bidang Kesehatan dan Bioteknologi. Medicinus, 29(1), 31-39. 
Jurnal PIKOM (Penelitian Komunikasi dan Pembangunan)

Vol. 21 No. 1 Juni 2020 